\title{
Climate Change as Apocalypse
}

\section{Gerbern S. Oegema, McGill University}

Abstract: The last couple of decades have revealed numerous consequences related to pollution and the impact of climate change. Natural disasters seem to have become part of our daily landscape; less than two years ago the whole continent of Australia was consumed by devastating forest fires, the Western part of the United States also experienced one of its worst wildfires in almost a century, while the ice cap in the North pole is melting and the permafrost of the Canadian and Russian tundra is disappearing. How can we deny the impacts of climate change as all of these catastrophes are unfolding before our very eyes? This conscious awareness of our planet's rapid deterioration has generated a number of movies and fictional novels about the coming apocalypse, dystopian society and the end of the world. Demonstrating that there is a growing sentiment of worry and anxiety for the future of the planet and of humankind. In this article I propose to examine the anxieties surrounding the impact of climate change and its potential connection the apocalyptic literature.

Keywords: Apocalypticism; Climate Change; Biblical Studies; Worldview.

$\mathrm{L}$

evels of anxiety especially among young people has risen at a phenomenal rate in the last several decades. Recent rises in anxiety surrounding the future can be seen within popular culture as apocalyptic and post-apocalyptic fiction has become overwhelmingly popular not only in films and fictional literature but in every form of media possibly imaginable. The apocalyptic and post-apocalyptic themes - a recognized fictional genre - have found themselves in a recent list of top 1,000 films, novels, television series, and music, with most of them being recent: eighty percent of them since 1970 and fifty percent in the last twenty years. ${ }^{2}$ It appears that anxiety surrounding climate change impact and popular culture's interest in apocalypticism seem to go hand in hand, as many believe that climate change may very well result in the end of our world. This article will examine current discussion around climate change as possibly reflecting and generating an apocalyptic worldview. To do so, I will first give a brief history of research on apocalypticism and then see whether the discussion around climate change is comparable with key aspects of an apocalyptic worldview. Whereas there is no consensus about a definition of the term "apocalypticism," many scholars agree that it refers mostly to a phenomenon, mindset or worldview, and that it can often, but not exclusively, be found in apocalyptic writings as a distinguishable genre, especially but not exclusively in antiquity. ${ }^{3}$ Throughout history and culture apocalyptic literature has many times emerged and re-emerged in times of political and social crises (i.e., crisis theory), often marking changes

1. This article is based on three separate paper presentations delivered at different academic events. The first was on November 15-16, 2018, at RWTH Aachen University, the second was during the colloquium "Religion and Climate Change," September 20, 2019 (organized by myself and Professor David Goodin at the School of Religious Studies, McGill University), and the third was for the McGill Association of University Teachers in Montreal on September 22, 2020.

2. See Lorenzo DiTommaso, "Apocalypticism and Popular Culture," in The Oxford Handbook of Apocalyptic Literature, ed. John J. Collins (Oxford: Oxford University Press, 2014), 476-478.

3. For further discussion see John J. Collins, Bernard McGinn and Stephen Stein eds., The Encylopedia of Apocalypticism: Vol. I: The Origins of Apocalypticism in Judaism and Christianity (New York: Continuum, 1999). 
in the mindset of people, but hardly noticed by official historical records. ${ }^{4}$ A phenomena that we also see within antiquity, since changes in climate have always been part of the apocalyptic imagery.

When dealing with issues on a global scale, a comparison with apocalypticism makes sense for a number of reasons, as the apocalyptic worldview is not accustomed to talking about small things, and, like politics, carefully structures the narrative as "negotiated steps;" a give and take scenario. Many of the apocalyptic writings, then and now, tend to put things in a world embracing perspective and like to envision dramatic changes on a cosmic level; this is what the apocalypse is made of, not only in antiquity but throughout history. This is what our present world also seems to be heading towards or has already arrived at: a global context of mankind facing changes of a seismic and even cosmic nature. Therefore, to see an interest in apocalypticism re-emerge in our times, whether in the Bible, literary fiction, film, popular culture,${ }^{5}$ theology, ${ }^{6}$ and even in scientific discussions about climate change, could point to possible tectonic shifts in society and to changes in the mindset of people. ${ }^{7}$ Therefore, this is reason enough to take this mindset serious, alongside the actual and ongoing impact of climate change.

The question that then arises is: Can we learn from an apocalyptic worldview when dealing with climate change? However, one must bear in mind that because apocalyptic worldviews deal more with mentalities and mindsets than with science, the question will be approached from the humanities and not from an exact sciences perspective. To be more precise: Can we detect certain ways of apocalyptic thinking in present-day cultural expressions about climate change? When I say "cultural expressions" I refer here to discussions of climate change in movies, literature, music, popular culture, politics and religion. However, before we can do that, we need to ask what we mean by "apocalyptic" and its various derivatives and dive a bit into the history of its research. Then we will discuss what one can categorize as an "apocalyptic worldview" and finally we will examine whether we can find any elements of an apocalyptic worldview in modern-day discussions about climate change.

\section{History and Reception}

As most scholars ${ }^{8}$ agree, apocalypticism begins in the Hebrew Bible and is related to prophecy. It finds its first climax in the Book of Daniel and the Maccabean Revolt in 167-164 BCE, and their common

4. See Ulrich H. J. Körtner, The End of the World: A Theological Interpretation, 1st ed. (Louisville, Ky.: Westminster/John Knox Press, 1995).

5. See DiTommaso, "Apocalypticism and Popular Culture."

6. See Pope Francis, Laudato Si': On Care for Our Common Home (Encyclical, 2015), http://www.vatican.va/content/ francesco/en/encyclicals/documents/papa-francesco_20150524_enciclica-laudato-si.html.

7. Just before traveling to Aachen to attend the conference scheduled for November 15-16, 2018, there were several demonstrations in various countries such as Canada, Germany, and Belgium, against inadequate action on climate change. Since then, many more demonstrations have taken place under the leadership and inspiration of Greta Thunberg. In addition, different people have been dealing with the current deteriorating state of our environment in highly creative ways. For instance, a cookbook titled Joe Beef: Surviving the Apocalypse: Another Cookbook of Sorts was published on renowned Montreal chef Joe Beef in 2018 to show readers how to "survive" the Joe Beef way.

8. Some of these scholars are: F. Lücke, Versuch einer vollständigen Einleitung in die Offenbarung des Johannes oder allgemeine Untersuchungen über die apokalyptische Litteratur (Bonn: Weber 1852); E. Reuss, Die Propheten (Braunschweig: Schwetschke 1892); A. Hilgenfeld, Messias Judaeorum, libris eorum Paulo ante et Paulo post Christum natum conscriptis illustratus (Leipzig: Fues 1869); Hermann Gunkel, Schöpfung und Chaos in Urzeit und Endzeit: eine religionsgeschichtliche Untersuchung über Gen. 1 und Ap. Joh. 12. Mit Beiträgen von Heinrich Zimmern (Göttingen: Vandenhoeck \& Ruprecht, 1895); F. Mowinckel, The Spirit and the Word. Prophecy and Tradition in Ancient Israel (Minneapolis: Augsburg Press 2002); John J. Collins ed., Apocalypse. The Morphology of a Genre, Semeia 14 (Missoula: Scholars Press, 1979); Christopher Rowland, The Open Heaven: a Study of Apocalyptic in Judaism and Early Christianity 
resistance against the Syrian oppression. During the Greco-Roman period apocalypticism dominated the sectarian movement associated with some of the Dead Sea Scrolls, as well as the Jesus movement, influenced the Bar Kochba Revolt, until Rabbinic Judaism began to transform its more radical elements into a more general messianic hope for the future. This hope of a coming savior or liberator is a dominant feature of the New Testament and the Early Church, which influenced John the Baptist, Jesus of Nazareth and the Apostle Paul, and particularly the Revelation of John and its resistance against the Roman Empire. The messianic theme found its way into many later Judeo-Christian apocalyptic traditions that persevered well into Late Antiquity, the Qur'an, and the Middle Ages, and continues to thrive still today. ${ }^{9}$ However, for the most part, the term "apocalyptic," in the modern present-day setting, appears to be used as a rather general term for everything with a doomsday scenario, which is often combined with huge natural catastrophes. This in turn is then popularized in movies and on the internet. Thus, to avoid any confusion we will move on to define what is intended when we use such terms as "apocalyptic" and "apocalypticism."

\section{Definition of "Apocalypticism"}

Whereas there is no consensus on how to define "apocalypticism," the term "apocalyptic imagination" was coined by John J. Collins, who is not only the author and editor of many books on the subject matter, but is also the co-editor of the Encyclopedia of Apocalypticism. ${ }^{10}$ Collins has spearheaded research into apocalypticism since the 1970s, originally in response to a booklet written by Klaus Koch entitled Ratlos vor der Apokalyptik (1970). ${ }^{11}$ Despite the booklet being quite short, it led to a very productive period of research that still continues to generate questions and queries amongst scholars today. ${ }^{12}$ Not only did Koch's booklet mark a period of rediscovery in the relevance of apocalypticism, it was written in a period of modern history which also saw a growing interest in social and anti-war protests, student revolts,

(New York: Crossroad, 1982); Paul D. Hanson, The Dawn of Apocalyptic: the Historical and Sociological Roots of Jewish Apocalyptic Eschatology, revised Edition (Philadelphia: Fortress Press, 1979); Johann Michael, Schmidt, Die jüdische Apokalyptik: Die Geschichte ihrer Erforschung von den Anfängen bis zu den Textfunden von Qumran, 2nd ed. (NeukirchenVluyn: Neukirchener Verlag, 1976).

9. See Gerbern S. Oegema, Zwischen Hoffnung und Gericht. Untersuchungen zur Rezeption der Apokalyptik im frühen Christentum und Judentum. Wissenschaftliche Monographien zum Alten und Neuen Testament, Vol. 82 (NeukirchenVluyn: Neukirchener Verlag, 1999); Apokalypsen Jüdische: Schriften aus hellenistisch-römischer Zeit VI.1.5. (Gütersloh: Gütersloher Verlagshaus, 2001); "Conceptions de l'âge messianiques dans le Judaïsme," in Les représentations du temps dans les religions, ed. V. Pirenne-Delforge and Ö. Tunca, (Genève: Librairie DROZ S.A., 2003): 75-85; "Die DanielRezeption in der Alten Kirche," in Europa: Tausendjähriges Reich und Neue Welt: Zwei Jahrtausende Geschichte und Utopie in der Rezeption des Danielbuches, eds. M. Delgano, K. Koch and E. Marsch (Friburg-Stuttgart: UniversitätsverlagKohlhammer, 2003): 84-104; The Apocalyptic Interpretation of the Bible: Essays on Apocalypticism and Biblical Interpretation in Early Judaism, the Apostle Paul, the Historical Jesus and Their Reception History (Edinburgh: T. \& T. Clark / Continuum, 2012); "Back to the Future in the Early Church: The Use of the Book of Daniel in Early Patristic Eschatology," in The Function of Ancient Historiography, eds. Patricia Kirkpatrick and Timothy Goltz (Edinburgh: T. \& T. Clark, 2008): 186-198; "The Heritage of Jewish Apocalypticism in Late-Antique and Early Medieval Judaism, Christianity and Islam," in Vehicles of Transmission, Translation, and Transformation in Medieval Cultures, eds. Robert Wisnovsky et al. (eds.), (Turnhout: Brepols Publishers, 2011): 103-129.

10. See John J. Collins ed., Apocalypse: The Morphology of a Genre, Semeia 14 (Missoula: Scholars Press, 1979); John J. Collins, Bernard McGinn and Stephen Stein eds., The Encylopedia of Apocalypticism: Vol. I: The Origins of Apocalypticism in Judaism and Christianity (New York: Continuum, 1999); John J. Collins, "Introduction: The Genre Apocalypse Reconsidered," in Apocalypse, Prophecy, and Pseudepigrapha: On Jewish Apocalyptic Literature (Grand Rapids: Eerdmans 2015).

11. Whereas the term "apocalypticism" and its German equivalent "Apokalyptik" refer more to a phenomenon, mindset or worldview, the expression "apocalyptic imagination" tries to describe the creative process behind it, and "apocalypse" is the actual literary genre, in which both are mostly found.

12. For further discussion see Collins, McGinn and Stein eds., The Encylopedia of Apocalypticism. 
liberation theology, feminism, and, especially important to our discussion, climate change. It was a time of industrialization and capitalism that had no mercy for the planet and led to pollution everywhere. These events were occurring at the same time as a report was being published by the Club of Rome in 1975, who tried to warn that economic growth could not continue because of resource depletion. These shifts and interests in apocalypticism and climate change, although they may seem to be correlated, are quite independent from one another and in no way is the author of this article trying to suggest that they are directly connected. However, it was no coincidence that this all happened at the same time.

One aspect of apocalypticism is, namely, its sensitivity to reflect on or represent the Zeitgeist or mindset of an epoch, whether in antiquity or in modern times. Collins himself focuses both on the genre "apocalypse," as researched and outlined in the thematic Journal Semeia $14,{ }^{13}$ and what exactly constituted as the characteristics of the genre. This marks one direction, which research into apocalypticism has taken, namely a more literary one. There are other approaches as well, but for the purpose of this article we will use the definition of the genre "apocalypse" offered by Collins, as it has defined much of later scholarship, albeit mostly of a literary and historical character:

A genre of revelatory literature with a narrative framework, in which a revelation is mediated by an otherworldly being to a human recipient, disclosing a transcendent reality which is both temporal, insofar as it envisages eschatological salvation, and spatial insofar as it involves another, supernatural world. ${ }^{14}$

A definition, for our particular purposes, is necessary, as apocalyptic literature as a whole is a difficult genre to analyze, let alone when trying to understand something even more vague like the phenomenon "apocalypticism." For one, it is surely not limited to the Hebrew Bible, but is found in many ancient Near Eastern cultures as well as other cultures. However, as to date there is no consensus on a definition of apocalypticism, there exist different methods or approaches to study the phenomenon, whether as a literary genre, as an historical phenomenon, or as a world view, but there is also the question of its social relevance and relation to other worldviews both philosophical and theological. This complexity makes the task of defining apocalypticism quite difficult, which is why many scholars prefer to identify its key aspects instead of trying to come to a definition. ${ }^{15}$ This is partly due to the inter-cultural and crosshistorical nature of the phenomenon. Apocalypticism is found in Judaism, Christianity and Islam as well as in ancient Greek, Roman and Egyptian cultures. Moreover, the phenomenon also appears in early modern Maya culture, in Hinduism, in twentieth-century Japan and contemporary American popular culture (i.e., Hollywood movies). In other words, to get a sense of the connections between the study of apocalypticism and worldviews, it is worth having a brief look at the history of this research. Coming from there we can then better define its present-day relevance, especially in light of climate change.

\section{History of Research}

According to the histories of research of Joachim M. Schmidt and John J. Collins, ${ }^{16}$ the academic study of apocalypticism found its origin in the investigations of the Book of Daniel and the Revelation of

13. Collins, Apocalypse: The Morphology.

14. Collins, Apocalypse: The Morphology, 9. Collins later refined his definition of approach to the genre "apocalypse." Also, see his introduction in Apocalypse, Prophecy, and Pseudepigrapha.

15. Patrick Becker and Steffen Jöris, "Towards a Scientific Designation: Apocalypticism in Biblical and Modern Studies," Horizons in Biblical Theology 38, no.1 (2016): 22-44.

16. See: Johann M. Schmidt, Die jüdische Apokalyptik: Die Geschichte ihrer Erforschung von den Anfängen bis zu den 
John, and in the early nineteenth century reached its first culmination in the concise overviews of Friedrich Lücke, Eduard Reuss and Adolf Hilgenfeld. ${ }^{17}$ These overviews allowed for the development of the history of literature as well as the religion- and tradition-historical approaches or models of explanations of the twentieth century. ${ }^{18}$ However, some of these earlier overviews can still be of relevance today, especially if they are adapted to and incorporated with newer discoveries and methodological innovations from the Dead Sea Scrolls to social scientific approaches. ${ }^{19}$

Whereas Joachim Schmidt mainly discusses older German scholarship on apocalypticism, John J. Collins offers an overview of more recent scholarship and predominantly English-speaking studies. In the work of Klaus Koch and the members of the Apocalypse Group of the Society of Biblical Literature's Genre Project, Collins sees two important contributions to the modern study of apocalypticism. In the scholarship of Klaus Koch, a differentiation is made between "apocalypse" as literary genre and "apocalypticism" as historical movement. After the literary, history of religion, tradition-historical and newer literary approach of J. J. Collins - and other scholars - from the late eighteenth until the middle of the twentieth century, a newer approach to apocalypticism was formulated in the efforts to determine its social origins and settings. In Stephen L. Cook's book Prophecy and Apocalypticism: The Postexilic Setting (1995) he offers us his view on some of the so-called proto-apocalyptic texts and the groups he believes authored them. ${ }^{20}$

Contrary to the previous scholarship of Paul Hanson and Otto Plöger, Cook does not believe that apocalyptic groups are to be found among the socially and economically deprived classes or marginal and socially alienated figures. ${ }^{21}$ Instead, he turns to sociological and anthropological analyses of apocalyptic groups and attempts to typologically characterize them according to their relationship to their own society and to their own culture or that of others. This approach is predominantly motivated by the fact that apocalypticism emerged from a wide variety of social matrices and is guided by the leadership of different kinds of figures. So, instead of apocalypticism being the response of a small sect to a political crisis, apocalypticism may very well have originated from mainstream groups within a society, and represents a more universal mindset, and not simply a minority opinion. This would then pave the way for the intellectual history approach and more importantly for the hypothesis of a common apocalyptic worldview, which is well represented in a collection of articles edited by Gabriele Boccaccini and John J. Collins in their edited book, The Early Enoch Literature (2007). ${ }^{22}$ Boccaccini and Collins' edited book utilizes a comparitive methodology to analyse two different literary corpora which allows them to conclude that a commonly shared world view is indeed present in the literature examined. ${ }^{23}$

There are of course many other scholars that we could discuss in the field of apocalypticism but for the purposes of this article we will end this brief history of research here in order to move forward to the broader question of the intellectual dimension of apocalypticism and its relevance for today. In his book

Textfunden von Qumran, 2nd ed. (Neukirchen-Vluyn: Neukirchener Verlag, 1976); Collins, Apocalypse: The Morphology; Collins, McGinn and Stein eds., The Encylopedia of Apocalypticism; Collins, "Introduction: The Genre Apocalypse Reconsidered."

17. Lücke, Versuch einer vollständigen; Reuss, Die Propheten; Hilgenfeld, Messias Judaeorum.

18. Here referring to the works of Gunkel, Schöpfung und Chaos; Mowinckel, The Spirit and the Word; Hanson, The Dawn of Apocalyptic; Rowland, The Open Heaven.

19. Stephen L. Cook, Prophecy and Apocalypticism: The Postexilic Setting (Minneapolis: Fortress, 1995) and Schmidt, Die jüdische Apokalyptik, 249.

20. Minneapolis: Fortress Press, 1995. Cook looks specifically at Ezekiel 38-39; Zechariah 1-8 and Joel.

21. Hanson, The Dawn of Apocalyptic and Otto Plöger, Theocracy and Eschatology (Richmond, VA: John Knox, 1968).

22. Gabriele Boccaccini and John J. Collins eds, The Early Enoch Literature (Leiden: Brill, 2007).

23. The articles in this collection are also useful as an analogy to the problem of a relation between prophecy and apocalypticism, as the Dead Sea Scrolls offer many actualizing interpretations of the prophetic writings and 1 Enoch, which is an early representative of Jewish apocayticism. 
Weltangst und Weltende: Eine theologische Interpretation der Apokalyptik (1988) or, in English, The End of the World: A Theological Interpretation of Apocalypticism (1995), Ulrich Körtner addresses the issue of apocalyptic anxiety by offering a theological and philosophical evaluation of what is often referred to as "apocalyptic." 24 In particular, Körtner looks at how theology, responding in pastoral sensitivity, should deal with apocalyptic fears and anxieties. He concludes that real meaning and hope for the world is possible only after the world's inhabitants deal constructively with the stark reality of the world's end.

To attain his goal of demonstrating that apocalypticism is, and can be, relevant for theology today, Körtner delves deep into much of twentieth century intellectual history and sees various moments, in which the end of the world was thought of as philosophically and theologically relevant. Some of the reviews offered by Körtner:

- The Untergang des Abendlandes (the End of the West), by philosophers like Oswald Spengler (1918); written after the First World War and the Spanish Flu.

- Theories about the end of the world from a natural science point of view (see the work of Teilhard de Jardin, 1946); here trying to integrate the theory of evolution with the beliefs of the Catholic faith.

- The limits of economic growth (Club of Rome, 1975); the effects of economic expansion, exploitation and pollution and its impact on the environment.

- The atomic catastrophe (1982); the potential of the arms race and nuclear war to bring civilization to an end.

One cannot separate climate change from these broader trends in society, and obviously Körtner would have included climate change in his book, had the book been written in our contemporary setting, for this discussion can no longer be ignored. We should therefore add climate change to this list and reflect on the coming end of the world through human induced catastrophes.

\section{The Apocalyptic Worldview}

We now come to the question of this apocalyptic worldview: How to connect ancient apocalypticism with both intellectual history and with modern views about the end of world. When trying to summarize what ancient apocalypticism is as a phenomenon - and not so much as a literary genre or a feature of Ancient Jewish literature - the key characteristics of the apocalyptic worldview as depicted in the language of ancient mythology are follows:

- A myth of origin, and the search for the origin of evil in fallen demons;

- An ethical and cosmological dualism between good and evil;

- A dualism that can also be presented as God and Satan, Christ and Antichrist, angels and demons;

- A periodized and eschatological understanding of time;

24. Ulrich H.J. Körtner, The End of the World: A Theological Interpretation of Apocalypticism, trans. Douglas W. Slott (Westminster: John Knox Press, 1995). 
- Mankind's time on earth being limited between creation and eschaton (Urzeit and Endzeit);

- The understanding of the eschaton as a new creation arises;

- This, in addition to concepts like a messianic age, Golden Age, etc.;

- Before the new world there is a catastrophic end;

- A catastrophe, which is induced by humankind and for which the exact time can be calculated;

- The end or latter-day turn-around comes with the help of a divine being, often a messianic savior figure, of human or cosmic origin;

- An emphasis is placed on human sin, which is caused by fallen angels/demons, who are responsible for the evil in the world throughout history;

- Good and bad times interchange in a periodized history and are dependent on whether people repent and improve their behavior or not;

- The end is seen as catastrophic and unavoidable and the possibility of repentance, as found in prophetic literature, is less dominant in apocalyptic literature;

- The apocalyptic worldview is much more pessimistic and often has a great deal more detailed doomsday scenarios than other worldviews;

We derive these characteristics from an analysis of the multiple examples that are present in the "apocalypse" genre. These narratives are mainly from antiquity and they come to influence later JudeoChristian traditions, however, we often assume that these narratives reflect elements of a wider ancient apocalyptic worldview, as we also observe similar literary elements in other apocalyptic narratives from Greek and Roman to Iranian and Egyptian civilizations and beyond.

Having said this about the phenomenon "apocalypticism" as a linguistic mode within literature, we can therefore also open the possibility of a second dimension to apocalypticism, namely as an intellectual mode of thinking or psychological state of mind. This Zeitgeist of a certain epoch or expression thereof, maybe even a mindset, when stripped off its mythological language reveals a deeper and universal mindset, which could and can easily be adapted in other cultures and periods in history. This way of thinking reflects a much deeper sense of a universal Weltangst and a fear for the coming end of this world, a trend that can be nurtured by certain physical, social, economic, and political circumstances; and, depending on the situation, can be actualized or become dormant again, even in our contemporary setting. In other words, there may exist a dormant "Angst" in all of us that can be triggered through catastrophic events into a more global and deeper felt anxiety about the end of the world. 


\section{Relevance for Today}

When looking at this universal dimension of apocalypticism as an expression of a Zeitgeist, one can certainly connect it with the present-day debate about climate change and environmental catastrophes, maybe not as the outcome of what ancient apocalypses had predicted, but as expressions of a broader fear that our planet is nearing its end. This end is obviously scientifically argued for and is not based on mythological concepts, as our worldview is based on scientific facts and arguments. Specifically, we are using a Cartesian and technocratic worldview and methodology instead of an apocalyptic and demonological one. We argue on the basis of "cause-effect" and use statistics for all of our claims instead of relying on secret knowledge and magical practices. We have technical, medical, and climate experts instead apocalyptic authors and interpreters of the signs of the times. However, when the mythological worldview is unpacked, a theological approach to "la condition humaine" and postmodernism remains relevant, and it is worth looking at the communalities and shared interests.

Thus, the thesis of this article is that when one takes away the mythological character and language of the apocalyptic worldview and goes to the heart of its existential and theological message, there is still "something" there one can learn from. A comparison between an apocalyptic worldview as described above and a scientific approach to climate change in the context of modern-day society could result in the following observations:

- The industrial revolution and its pollution are, arguably, the starting point of how humankind began to impact climate change;

- Humankind can make positive and negative contributions to climate change;

- These changes can be championed by both sides, for example Donald Trump and Greta Thurnberg both are viewed as champions, but sit at opposite spectrums of the fight against climate change;

- History has demonstrated that the viability of a civilization fluctuates and moves from periods of bad to worse until a final projected potential collapse occurs;

- Humankind's time on earth is limited unless a final collapse can be avoided;

- If a collapse occurs there could be either a dystopian or utopian future, as has been the focus of many modern Hollywood movies;

- Additionally, a utopian future could either be triggered through another technological revolution or an alternate solution, for instance, a migration to another planet;

- Prior to dystopian or utopian scenarios, catastrophic events will force humankind to act;

- A catastrophe, produced by humankind and for which an exact time can be calculated according to scientific models; 
- The end or latter-day turn-around brings about a necessary unification of global powers and leaders, for example, a new world order, or a universal climate agreement;

- There is an emphasis on identifying the (human) cause of climate change, thus pointing the finger at greedy businesses and irresponsible politicians, who are the main cause of pollution and the negative impact on the environment;

- Better or worse conditions are predominantly dependent upon the involvement and the willingness of humankind to fight climate change;

- A potential reversal is only possible if people take the many warnings seriously, otherwise the coming end will be unavoidable and catastrophic;

- Thus, resulting in the observation that our present-day worldview is a great deal more pessimistic and often has a more detailed doomsday scenario than previous worldviews;

- As witnessed in both popular culture, movies, novels, music, etc. and in the growing anxiety and depression, especially among young people who are most effected by climate change;

\section{The Lessons that Must be Learned}

First, when connecting evil and sin (wrongdoing) to its potentially catastrophic outcomes, as apocalypses do, one can emphasize the human responsibility for, and contribution to, global warming and its already real and potentially future catastrophic outcomes. Once we acknowledge that humanity is and has been the cause of the planet's demise, we must also acknowledge that a certain momentum has already developed. Like in ancient apocalypses, the world seems to be heading towards a catastrophic end that cannot be stopped and is unavoidable. Second, one can learn from history; it is vital that we closely examine the responses and opposition to apocalyptic thinking and apocalyptic movements, especially from those who are in positions of power. Today, these past lessons can help us to deal not only with opposition, but with finding potential solutions. Third, examining and analyzing apocalyptic thinking and movements from the past, in which evil, human sin and catastrophe were closely interlinked, one can better understand the role of humankind and its responsibility vis-à-vis the earth. That is to say that climate change did not happen all of a sudden and humankind has been participating in impacting its environment from the moment human history began. Humanity's actions and non-actions from the beginning of time to the present is why we are heading towards a catastrophe. Thus, it is equally important that we understand past apocalyptic thinking and past responses to catastrophes to learn from humanity's mistakes and move towards a better path of action.

Moreover, through the interconnectedness of everything and everyone in apocalyptic literature namely, that the sin of the individual and of the group and of society at large has, in the end, both good and bad consequences for the whole earth - one needs to see the bigger picture. One cannot turn a blind eye and think that so long as right now all is well and there is no immediate danger that everything is fine, because the future of humanity and of the planet are all interconnected; if not today than tomorrow. The historical perspective also opens the possibility of real change and the chance of winning the fight against climate change to improve the life of future generations on earth. Obviously, I am not suggesting that we rely upon 
demonology and magic and calculations of the end of days, as found in apocalyptic texts of antiquity, but rather that we see the apocalyptic mindset through the historical perspective and combine it with statistical and scientific models. The apocalyptic narrative and discourse teaches us to place things in an historical perspective; to see how everything is connected to each other and how expressions of human concerns can function as wake-up calls as well as signs of hope.

What of the apocalyptic expectation of a new heaven and earth, paradise, messianic age or Golden Age you may ask? Technology and scientific advancements already offer many improvements to society and better quality of life, for both individuals and communities - this is evident just comparing today with just one generation ago. Artificial Intelligence may help us manage an ever growing and complex world, where we do not have to rely on a fantasy about migrating to Mars, but rather, provide solutions for the here and now and work towards improving the climate on our own planet. Finally, we have a pastoral responsibility as those, who understand and have access to this "higher knowledge" to care for those, who are in despair and sink into anxiety and depression because scientists are sounding the alarm; alerting us that the end of our world as we know it is much closer than we ever expected. Anxiety and depression are real and growing problems among young people, and are potentially linked to a doomsday mindset, or way of thinking, about the end of our planet. The apocalyptic dimension of climate change is one that cannot be ignored, it is not simply something that we can label as antiquarian; a thing of the past. It is a human response and presently it is calling humanity to act and engage. 


\section{Bibliography}

Becker, Patrick and Steffen Jöris. "Towards a Scientific Designation: Apocalypticism in Biblical and Modern Studies." Horizons in Biblical Theology 38, no. 1 (2016): 22-44.

Boccaccini, Gabriele and John Joseph Collins eds. The Early Enoch Literature. Leiden: Brill, 2007.

Charles, Robert Henry. A Critical History of the Doctrine of a Future life, in Israel, in Judaism, and in Christianity, or, Hebrew, Jewish, and Christian Eschatology from Pre-prophetic Times till the Close of the New Testament Canon. 2nd ed. London: A \& C Black, 1913.

Collins, John Joseph ed. Apocalypse. The Morphology of a Genre. Semeia 14. Missoula: Scholars Press, 1979.

- "Introduction: The Genre Apocalypse Reconsidered." In Apocalypse, Prophecy, and Pseudepigrapha: On Jewish Apocalyptic Literature. Grand Rapids: Eerdmans, 2015.

Collins, John Joseph, Bernard McGinn and Stephen Stein eds. The Encylopedia of Apocalypticism: Vol. I: The Origins of Apocalypticism in Judaism and Christianity. New York: Continuum, 1999.

Cook, Stephen L. Prophecy and Apocalypticism: The Postexilic Setting. Minneapolis: Fortress, 1995.

Di Tommaso, Lorenzo. “Apocalypticism and Popular Culture." In The Oxford Handbook of Apocalyptic Literature, 473-509. Edited by John J. Collins. Oxford: Oxford University Press, 2014.

Grabbe, Lester and Robert D. Haak, eds. Knowing the End from the Beginning: The Prophetic, Apocalyptic and their Relationships. London: T\&T Clark, 2003.

Gunkel, Hermann. Schöpfung und Chaos in Urzeit und Endzeit: eine religionsgeschichtliche Untersuchung über Gen. 1 und Ap. Joh. 12. Mit Beiträgen von Heinrich Zimmern. Göttingen: Vandenhoeck \& Ruprecht, 1895.

Hanson, Paul D. The Dawn of Apocalyptic: The Historical and Sociological Roots of Jewish Apocalyptic Eschatology, Revised Edition. Philadelphia: Fortress Press, 1979.

Hellholm, David. Apocalypticism in the Mediterranean World and in the Near East, 2nd Edition. Tübingen: Mohr, 1989.

Hilgenfeld, A. Messias Judaeorum, libris eorum Paulo ante et Paulo post Christum natum conscriptis illustratus. Leipzig: Fues 1869.

Koch, Klaus. Ratlos vor der Apokalyptik: eine Streitschrift über ein vernachlässigtes Gebiet der Bibelwissenschaft und die schädlichen Auswirkungen auf Theologie und Philosophie. Gütersloh: Mohn, 1970. 
Körtner, Ulrich H.J. The End of the World: A Theological Interpretation of Apocalypticism / Weltangst und Weltende: Eine theologische Interpretation der Apokalyptik [1988]. Translated by Douglas W. Slott. Westminster: John Knox Press, 1995.

Lücke, F. Versuch einer vollständigen Einleitung in die Offenbarung des Johannes oder allgemeine Untersuchungen über die apokalyptische Litteratur. Bonn: Weber, 1852.

McMillan, David, and Frederic Morin, eds. Joe Beef: Surviving the Apocalypse: Another Cookbook of Sorts. New York: Alfred A. Knopf, 2018.

Mowinckel, F. The Spirit and the Word. Prophecy and Tradition in Ancient Israel. Minneapolis: Augsburg Press, 2002.

Oegema, Gerbern S. Zwischen Hoffnung und Gericht. Untersuchungen zur Rezeption der Apokalyptik im frühen Christentum und Judentum. Wissenschaftliche Monographien zum Alten und Neuen Testament, Vol. 82. Neukirchen-Vluyn: Neukirchener Verlag, 1999.

Apokalypsen. Jüdische Schriften aus hellenistisch-römischer Zeit VI.1.5. Gütersloh: Gütersloher Verlagshaus, 2001.

. "Conceptions de l'âge messianiques dans le Judaïsme." In Les représentations du temps dans les religions, 75-85. Edited by V. Pirenne-Delforge and Ö. Tunca. Genève: Librairie DROZ S.A., 2003.

. "Die Daniel-Rezeption in der Alten Kirche." In Europa, Tausendjähriges Reich und Neue Welt. Zwei Jahrtausende Geschichte und Utopie in der Rezeption des Danielbuches, 84-104. Edited by M. Delgano, K. Koch, and E. Marsch. Friburg-Stuttgart: Universitätsverlag-Kohlhammer, 2003 .

- The Apocalyptic Interpretation of the Bible: Essays on Apocalypticism and Biblical Interpretation in Early Judaism, the Apostle Paul, the Historical Jesus and Their Reception History. Edinburgh: T. \& T. Clark / Continuum, 2012.

. "Back to the Future in the Early Church: The Use of the Book of Daniel in Early Patristic Eschatology." In The Function of Ancient Historiography, 186-198. Edited by Patricia Kirkpatrick and Timothy Goltz. Edinburgh: T. \& T. Clark, 2008.

- "The Heritage of Jewish Apocalypticism in Late-Antique and Early Medieval Judaism, Christianity and Islam." In Vehicles of Transmission, Translation, and Transformation in Medieval Cultures, 103-129. Edited by R. Wisnovsky et al. Cursor Mundi, UCLA Center for Medieval Studies, Turnhout: Brepols, 2012.

. "Prophecy and Apocalypticism." In The Apocalyptic Interpretation of the Bible: Essays on 
Apocalypticism and Biblical Interpretation in Early Judaism, the Apostle Paul, the Historical Jesus and Their Reception History, 3-16. Edinburgh: T\& T Clark / Continuum Edinburgh, 2012.

Plöger, Otto. Theocracy and Eschatology. Richmond, VA: John Knox, 1968.

Pope Francis, Laudato Si’: On Care for Our Common Home. Encyclical, 2015.

Reuss, E. Die Propheten. Braunschweig: Schwetschke 1892.

Rowland, Christopher. The Open Heaven: A Study of Apocalyptic in Judaism and Early Christianity. New York: Crossroad, 1982.

Schmidt, Johann M. Die jüdische Apokalyptik: Die Geschichte ihrer Erforschung von den Anfängen bis zu den Textfunden von Qumran, 2nd Edition. Neukirchen-Vluyn: Neukirchener Verlag, 1976.

Siegemund, Axel. "Umwelttechnik. Eine apokalyptische Praxis?" In Theologie im Konzert der Wissenschaften: Festschrift für Harry Noormann zum 70. Geburtstag, 167-82. Edited by Fuchs and Hofheinz. Stuttgart: Kohlhammer, 2018.

Spengler, Oswald. Der Untergang des Abendlandes. Umrisse einer Morphologie der Weltgeschichte. Vienna: Verlag Braumüller, 1918.

Yoshiko Reed, Annette. Fallen Angels and the History of Judaism and Christianity: The Reception of Enochic Literature. New York: Cambridge University Press, 2005. 